Dikirim: 28 Juni 2016

Diterbitkan: 1 Januari 2017

\section{Peran kader posyandu dalam pemberdayaan masyarakat Bintan}

\section{Role of posyandu cadres in empowering the community of Bintan}

Fino Susanto ${ }^{1}$, Mora Claramita ${ }^{2}$, Sri Handayani ${ }^{3}$

\begin{abstract}
Purpose: This study aimed to determine the role of posyandu cadres in empowering the community in Kawal village, Gunung Kijang district, Bintan regency. Methods: This study used a qualitative method with a case study design and purposive sampling technique, with the cadres of posyandu. Data collection was done by in-depth interviews and focus group discussion (FGD), with triangulation of sources and methods. Results: The role of cadres are as a health motivator, with the extension officers of the health and medical services as well as cadres being able to identify the needs, barriers and help to coordinate in providing health services. Conclusion: Posyandu cadres have high social spirit created by the combination of internal and external motivation, resources and potential as well as experience developing ability, with the social spirit capable of inspiring, activating, stimulating, mobilizing and motivating people.
\end{abstract}

Keywords: community empowerment; the role of cadres; posyandu

\footnotetext{
${ }^{1}$ Departemen Perilaku Kesehatan, Lingkungan dan Kedokteran, Fakultas Kedokteran, Universitas Gadjah Mada (Email: aldovalendra@yahoo.co.id)

${ }^{2}$ Departemen Ilmu Pendidikan Kedokteran, Fakultas Kedokteran, Universitas Gadjah Mada

${ }^{3}$ Institut Ilmu Kesehatan Yogyakarta
} 


\section{PENDAHULUAN}

Program kesehatan dunia menekankan potensi peran kader kesehatan untuk meningkatkan derajat kesehatan masyarakat (1). Kader kesehatan sangat diharapkan sebagai komponen integral tenaga kerja kesehatan untuk pembangunan kesehatan (2). Kader kesehatan diharapkan membantu masyarakat dalam mengadopsi perilaku gaya hidup sehat (3).

Survei Riskesdas 2010 menunjukkan 50\% balita di Indonesia tidak ditimbang secara teratur di posyandu. Sementara, jumlah posyandu yang tersebar di 33 provinsi di Indonesia sudah cukup banyak yaitu sekitar 330.000 posyandu (4). Di Kabupaten Bintan terdapat 146 posyandu pada tahun 2015 dan setiap posyandu terdiri dari 9 kader posyandu. Dari 146 posyandu yang sudah termasuk dalam klasifikasi purnama sebanyak 109 posyandu (74,66\%), meningkat 9,66\% dibandingkan tahun 2013 yaitu sebanyak 65,00\%, sedangkan yang mencapai klasifikasi mandiri di tahun 2015 sebanyak $11,64 \%$.

Jumlah posyandu ideal menurut Kementerian Kesehatan yaitu 1 posyandu untuk 100 balita (1:100). Jika dibandingkan dengan jumlah anak balita tahun 2015, maka kebutuhan posyandu di kabupaten Bintan sudah terpenuhi (5). Keberadaan posyandu memiliki peran penting di masyarakat, namun secara nasional hanya 27,3\% rumah tangga memanfaatkan posyandu. Sebanyak 62,5\% rumah tangga merasa tidak membutuhkan posyandu, dan 10,2\% rumah tangga tidak menggunakan fasilitas posyandu untuk alasan lain (6). Layanan posyandu harus didukung oleh kesiapan kader dalam memberikan layanan dasar. Persepsi positif harus dimiliki setiap kader agar layanan kesehatan dapat berjalan maksimal. Partisipasi kader yang rendah berdampak pada kesadaran masyarakat untuk datang dalam kegiatan pemantauan status gizi anak (7).

Studi pendahuluan menunjukkan bahwa motivasi seseorang bergabung menjadi kader adalah ingin mendapatkan pengetahuan dan meningkatkan derajat kesehatan balita. Beberapa hambatan pelaksanaan posyandu yang ditemui adalah masyarakat tidak paham urgensi pemantauan tumbuh kembang balita dan tidak mengetahui peran keberadaan posyandu. Kader sebagai bagian dari masyarakat berperan ganda dalam meningkatkan keaktifan masyarakat dalam kegiatan posyandu. Penelitian bertujuan mengetahui peran kader posyandu dalam upaya pemberdayaan masyarakat keluarahan kawal kecamatan Gunung Kijang kabupaten Bintan.

\section{METODE}

Penelitian kualitatif menggunakan pendekatan studi kasus tunggal, untuk mendeskripsikan peran kader posyandu balita di wilayah kelurahan Kawal dalam memberdayakan masyarakat. Pengambilan data informan dilakukan dengan metode wawancara mendalam dan focus group discussion (FGD). Informan penelitian ini adalah kader posyandu di kelurahan Kawal yang diambil secara purposif. Ada 5 responden dan 5 informan yang dilakukan wawancara mendalam, 8 informan peserta FGD pada kelompok kader dan 6 informan peserta FGD pada kelompok masyarakat pengguna layanan posyandu. penelitian ini dilakukan pada bulan November 2015 sampai Januari 2016. Semua data ditranskrip, dikoding melalui software opencode, dikategorikan untuk mendekatkan data-data dengan makna serupa. Setiap kategori dihubungkan untuk mendapatkan pola tertentu berupa axial coding. Setelah semua tahap terlaksana, maka diperoleh data dan tersaji dalam bentuk narasi, tabel dan gambar.

\section{HASIL}

Partisipasi sebagai kader posyandu dilatarbelakangi faktor internal dan eksternal. Faktor internal menjadi kader posyandu di kelurahan Kawal yaitu jiwa sosial tinggi untuk membantu orang lain di bidang kesehatan dan keinginan untuk mendapat pengetahuan tentang kesehatan, terutama anak dan ibu hamil, pengetahuan tentang tumbuh kembang balita, untuk meningkatkan kesehatan keluarga.

"menjadi kader harus mempunyai jiwa sosial tinggi, terutama peduli terhadap lingkungan dan anak-anak dan ingin memajukan kesehatan di lingkungan sendiri" (Kader 1)

"Saya orang senang berbagi ilmu dan memiliki ras ingin tahu tinggi. Kalau sekolah lanjut, sepertinya tidak mungkin. Jadi saya ingin meningkatkan keilmuan secara non formal dan saya ingin menambah wawasan. Oleh karena itu saya bergabung menjadi kader posyandu. Sejak bergabung di posyandu, pengetahuan semakin bertambah, dari tidak mengerti menjadi lebih paham" (FGD Kader)

Faktor eksternal yang melatarbelakangi adalah ingin membantu program pemerintah untuk membentuk anak sehat dan mempunyai layanan kesehatan keluarga yang mudah dijangkau. Kesadaran untuk terlibat aktif dalammembangun kesadaran masyarakat untuk mengambil bagian dalam meningkatkan derajat kesehatan masyarakat terutama anak-anak. 
"Kami ingin membentuk anak itu biar sehat. Biar apa yang diharapkan pemerintah itu tercapai. Di sini kan balita banyak. Jadi kami berusahalah.” (Kader 5)

Kader posyandu memberi layanan kesehatan, dari pendaftaran, penimbangan bayi dan balita, pencatatan, penyuluhan, pemberian vitamin A dan imunisasi. Penyuluhan kesehatan tentang perilaku hidup bersih dan sehat dan kebersihan lingkungan.

"Kegiatan posyandu sistem 5 meja berjalan lancar, terdiri dari pendaftaran, penimbangan. pencatatan, keempatnya, meja penyuluhan, imunisasi, pelayanan kesehatan" (FGD Kader)

Masyarakat belum mempunyai kesadaran untuk menimbang balita secara rutin. Sebagian masyarakat menganggap kegiatan penimbangan balita kurang bermanfaat. Mereka menilai bahwa untuk mengetahui berat badan balita tidak susah datang ke posyandu. Penimbangan berat badan balita dapat dilakukan dimana saja, seperti kedai/toko, asalkan di tempat itu tersedia timbangan. Selain itu sebagian masyarakat memiliki persepsi salah terhadap kegiatan imunisasi di posyandu, seperti anggapan demam pasca imunisasi (KIPI) dapat mengganggu kesehatan anak.

"Masyarakat kurang percaya terhadap posyandu, untuk apa susah payah ke posyandu untuk menimbang. Kami pergi ke kedai timbang, sama saja timbangan nya. Itulah yang paling berat. Paling berat itu merubah pola pikir mereka” (Kader 2)

"Ada orang tua yang tidak bersedia membawa anaknya ke posyandu. Alasannya karena anak takut disuntik, demam. Selanjutnya kader datang ke rumah. Kemudian menyampaikan bahwa ibu nya sedang bekerja, sehingga tidak bisa mengantar anak nya" (Staf Puskesmas)

Kader posyandu membangun partisipasi dengan melibatkan masyarakat dalam kegiatan gotong royong untuk menyediakan tanaman obat keluarga dan memelihara kebersihan lingkungan.

"Gotong royong mengelola kebun. Sebelumnya musim kemarau maka biasanya kami biasanya mengajak warga untuk membersihkan secara bersama. Kemarin dari kami mengikui seminar pemanfaatan tanah pekarangan. Kemudian kami menganjurkan agara masyarakat untuk menanam seperti TOGA untuk bumbu masak dan bunga” (Kader 4)

Kebutuhan terhadap peningkatan kemampuan dan keterampilan kader posyandu dalam memberi layanan kesehatan kepada masyarakat, dengan memberikan pelatihan. Pengetahuan setelah mengikuti pelatihan disosialisasikan pada kader lain yang tidak mengikuti pelatihan atau penataran (peer educator).
"Saya sudah pernah mengikuti pelatihan untuk sosialisasi balita, perkembangan anak, penambahan gizi. Wajib menyusui, membuat PMT, cara menimbang yang benar dan baik, untuk mengisi ke KMS, tinggi badan" (FGD Kader)

Kader posyandu dibekali buku panduan untuk memberi layanan kesehatan kepada masyarakat. Kader posyandu dapat mempelajari buku panduan tersebut untuk memberikan pelayanan dengan "Sistem 5 Meja”. Kader posyandu diminta rutin mengawasi tumbuh kembang balita.

"Saya mengetahui pak karena sudah ada panduan nya. Setiap dari pendaftaran langsung ke penimbangan, pengisian KMS. Dari KMS, kami melihat status imunisasi nya sudah sampai dimana, umurnya berapa, berat badannya berapa, untuk sehari-harinya itu sudah sampai mana. Perkembangan anak itu dipantau melalui buku. Jika kurang, maka kami menyampaikan kepada ibu balita" (Kader 3)

Pemberian doorprize merupakan salah satu cara untuk menarik masyarakat agar mengikuti kegiatan posyandu. Hadiah diberikan sebagai penghargaan kepada orang tua balita yang telah mengikuti kegiatan posyandu selama 5 tahun. Pemberian hadiah-hadiah tersebut menggunakan uang kas dari iuran kader posyandu.

"Kami selalu memotivasi mereka dengan memberikan doorprize selama tiga bulan sekali. Kalau untuk balita dalam bentuk baju, bekal anak, dan nampan-nampan. Sedangkan peralatan balita itu sendiri, karena kita mempunyai keinginan untuk memajukan posyandu maju. Jika tidak mempunyai kas, kami mendiskusikan bersama kader" (Kader 4)

Pelatihan dapat memberikan manfaat untuk kader posyandu. Kader mempunyai kemampuan untuk memberikan pendidikan dan penyadaran kepada masyarakat dalam layanan kesehatan mandiri berupa pertolongan pertama dan pengobatan sendiri jika terjadi diare, penyuluhan gizi, penyuluhan penyakit wabah, mengajak partisipasi aktif orang tua melalui kunjungan ke rumah, kelas ibu hamil dan balita.

Kader posyandu mampu memberikan penyuluhan tentang kebersihan lingkungan untuk mencegah demam berdarah, campak, dan penyakit kaki gajah. Kader dapat memberikan pengertian tentang kejadian ikutan pasca imunisasi (KIPI) kepada orang tua balita.

"Ada yang mengajari untuk membuat laruran orali, membersihkan kamar mandi, misalnya bak dikuras, diberikan abate "(Masyarakat 1)

"Misalnya ada, orang yang tidak pernah ke posyandu untuk membawa anak nya tadi. Dia pasti akan mengajak secara perlahan untuk ke posyandu. Karena pemikiran 
orang tidak selalu mengantar anak ke posyandu. Contohnya suntik imunisasi, anaknya demam, besoknya demam, pasti menjadi masalah. Oleh karena itu perlu diberikan pemahaman secara perlahan diajak. Mungkin bulan ini tidak ikut, bulan depan diajak. Jangan sampai terjadi ada anak di bawah garis merah" (FGD Kader)

Kader posyandu memberikan pendidikan kepada orang tua tentang tumbuh kembang balita melalui “Kelas Balita”. Kelas balita adalah media pendidikan ibu tentang merawat balita pada masa tumbuh kembang, kesehatan, dan perkembangan sosial dan psikologis anak. Kegiatan kelas balita dilakukan setiap enam bulan sekali.

"Ada kelas balita setiap enam bulan sekali. Kelas balita untuk memantau perkembangan anak. Kalau posyandu khusus untuk pemantauan balita. Kalau kelas balita khusus untuk membina ibu. Seperti sebelum makan cuci tangan menggunakan sabun. Kalau bermain harus memakai alas kaki, terakhir tentang cara penyajian makanan" (Kader 2)

\section{BAHASAN}

Semangat sosial menggambarkan satu komponen penting dalam pemberdayaan masyarakat meliputi kemampuan menginspirasi, mengantusiasi, mengaktivasi, menstimulasi, menggerakkan dan memotivasi orang lain untuk melakukan tindakan (8). Peran kader posyandu balita dalam pemberdayaan masyarakat dibentuk dari motivasi internal dan eksternal, hambatan, sumber daya, potensi dan pengalaman mengembangkan kemampuan. Kader posyandu berperan sebagai pemberdaya masyarakat. Kader memiliki kemampuan untuk membuat masyarakat ikut terlibat dengan semangat sosial. Semangat sosial kader kesehatan mampu memainkan peran penting dalam pemberdayaan masyarakat (9).

Pendidikan masyarakat yang rendah menyebabkan sebagian besar masyarakat belum terbuka terhadap informasi kesehatan dan masih berpegang pada nilai adat/budaya di kelompok masyarakat yang sering kali tidak mendukung perilaku kesehatan. Dukungan tokoh masyarakat terhadap posyandu relatif kurang sehingga penyelenggaraan layanan kesehatan secara mandiri menemui hambatan dalam hal penggalangan dana kegiatan posyandu. Namun di tengah lingkungan yang mempunyai kesadaran dan pengetahuan pendidikan rendah, terdapat sejumlah anggota masyarakat yang memiliki kesadaran memperbaiki kesejahteraan keluarga dengan meningkatkan derajat kesehatan ibu dan anak. Kesadaran tersebut menumbuhkan keinginan sebagian anggota masyarakat untuk aktif menjadi kader posyandu.
Layanan kesehatan kepada masyarakat yang bersumber dari masyarakat merupakan proses pemberdayaan masyarakat. Usaha mewujudkan pusat layanan kesehatan masyarakat yang dikelola sendiri oleh masyarakat merupakan paradigma pembangunan kesehatan berdasarkan kebutuhan masyarakat (10).

Semangat membantu masyarakat tanpa imbalan dalam bidang kesehatan merupakan bentuk keikhlasan yang dimiliki kader. Koordinator kader adalah bidan desa. Masyarakat dan kelompok sosial yang terbentuk memiliki bobot resiprositas kuat melahirkan modal sosial tinggi, saling membantu (11).

Potensi kerukunan masyarakat mampu menopang hubungan antar komunitas dan mencapai tujuan bersama terutama untuk memenuhi kebutuhan kesehatan masyarakat. Potensi kerukunan tersebut merupakan nilai sosial yang menciptakan harmoni dalam mendorong partisipasi masyarakat untuk memenuhi kebutuhan kesehatan secara mandiri (12).

Posyandu merupakan forum komunikasi dan pelayanan kesehatan masyarakat yang mempunyai nilai strategis untuk pengembangan sumber daya manusia. Penemuan tersebut sesuai dengan penelitian Effendy, posyandu adalah pusat pelayanan kesehatan keluarga dan keluarga berencana yang dikelola untuk dan oleh masyarakat melalui dukungan teknis petugas kesehatan dalam pencapaian norma keluarga kecil bahagia sejahtera (13).

Komitmen dapat terwujud, jika kader posyandu secara bergilir memperoleh kesempatan untuk mengikuti kegiatan pelatihan dan sosialisasi, terutama kader baru. Sementara, kader posyandu yang belum mengikuti kegiatan tersebut dapat menggunakan buku panduan posyandu untuk melaksanakan kegiatan posyandu. Kegiatan ini menjadi sarana penguatan peranan kader.

Pendidikan layanan kesehatan secara langsung dapat membantu kader posyandu untuk mengambil peran dalam memberdayakan masyarakat. Pelatihan merupakan mekanisme penggunaan sumber daya eksternal. Jenjang pelatihan dan keikutsertaan organisasi berpengaruh pada kelangsungan kader. Pelatihan kader dimaksudkan untuk meningkatkan pemahaman dan keterampilan dalam pelaksanaan tugas di posyandu (14).

Peran masyarakat dalam memberikan pelayanan kesehatan secara mandiri dengan mengoptimalkan sumber daya dan potensi yang tersedia di masyarakat. Peran-peran tersebut terbagi dalam tiga kelompok yaitu motivator kesehatan, penyuluhan dan pelayanan kesehatan. 
Motivator kesehatan bertugas menggerakkan masyarakat untuk mengikuti kegiatan posyandu, menanam TOGA, menggalang dana swadaya masyarakat, dan perbaikan gizi balita. Penyuluh kesehatan berperan memberikan edukasi tentang perilaku PHBS, kebersihan, sanitasi lingkungan. Pelayanan kesehatan meliputi pendaftaran anggota posyandu, penimbangan bayi dan balita, pencatatan perkembangan balita, penyuluhan tumbuh kembang anak, pemberian kapsul vitamin A, pemberian imunisasi bayi dan balita. Pemberdayaan masyarakat terjadi karena komitmen dan integritas kader posyandu dalam memahami kebutuhan masyarakat (15).

\section{SIMPULAN}

Kader posyandu berperan sebagai motivator kesehatan, penyuluh kesehatan dan pemberi layanan kesehatan melalui posyandu. Pemberdayaan masyarakat tercipta dari faktor motivasi untuk meningkatkan kesehatan keluarga dan masyarakat, kemampuan mengidentifikasi kebutuhan dan hambatan layanan kesehatan, dan memahami sumber daya yang tersedia. Perlu perencanaan dengan strategi pemberdayaan masyarakat dalam mengatasi partisipasi masyarakat yang masih rendah dengan melibatkan tokoh masyarakat, adat, pemerintahan dan organisasi masyarakat..

\begin{abstract}
Abstrak
Tujuan: Penelitian ini bertujuan mengetahui peran kader posyandu dalam memberdayakan masyarakat di kelurahan Kawal kecamatan Gunung Kijang kabupaten Bintan. Metode: Penelitian menggunakan metode kualitatif dengan rancangan studi kasus dan teknik sampling purposive sampling, terhadap kader posyandu, pengumpulan data dilakukan dengan wawancara mendalam dan focus group discussion (FGD). Kami melakukan triangulasi sumber dan metode. Hasil: Peran kader di masyarakat adalah sebagai motivator, penyuluh dan pelayanan kesehatan. Kader dapat mengidentifikasi kebutuhan, hambatan serta berkoordinasi dalam memberikan layanan kesehatan. Simpulan: Kader posyandu memiliki semangat sosial tinggi yang dibentuk dari kombinasi motivasi internal dan eksternal, sumber daya, potensi dan pengalaman dari pengembangan kemampuan.
\end{abstract}

Kata kunci: pemberdayaan masyarakat; peran kader; posyandu

\section{PUSTAKA}

1. Kahn RG. The Role of Community Health Workers in Northeast Brazil. Stanford Undergraduate Research Journal Spring. 2008;7:52-5.

2. Perry H, Zulliger R. How effective are community health workers. An overview of current evidence with recommendations for strengthening community health worker programs to accelerate progress in achieving the health-related Millennium Development Goals. Baltimore: Johns Hopkins Bloomberg School of Public Health. 2012 Sep.

3. Martinez J, Knickman JR. Community health workers: A critical link for improving health outcomes and promoting cost-effective care in the era of health reform. New York: New York State Health Foundation. 2010 Oct.

4. Badan Penelitian dan Pengembangan Kesehatan Departemen Kesehatan RI. Riset Kesehatan Dasar Tahun 2010. Jakarta; 2011.

5. Dinas Kesehatan Bintan. Profil Kesehatan. Kabupaten Bintan; 2012.

6. Iswarawanti DN. Kader posyandu: Peranan dan tantangan pemberdayaannya dalam usaha peningkatan gizi anak di indonesia. Jurnal Manajemen Pelayanan Kesehatan. 2010 Dec;13(04).

7. Rurensia Puspitasari N. Persepsi Kader Posyandu Tentang Pentingnya Manfaat Penimbangan Berat Badan Balita Di Posyandu (Doctoral dissertation, Universitas Muhammdiyah ponorogo).

8. Ife J, Tesoriero F. Alternatif pengembangan masyarakat di era globalisasi community development. Yogyakarta (ID): Pustaka Pelajar. 2008.

9. Balcazar H, Lee Rosenthal E, Nell Brownstein J, Rush $\mathrm{CH}$, Matos S, Hernandez L. Community health workers can be a public health force for change in the United States: three actions for a new paradigm. American journal of public health. 2011 Dec;101(12):2199-203.

10. Alfitri. Community Development, Teori dan Aplikasi. Pustaka Pelajar, Yogyakarta;2011.

11. Nasir SU, Ahmed RU, Kurniasari MI, Limato RA, De Koning K, Tulloch O, Syafruddin D. Context analysis: close-to-community maternal health providers in South West Sumba and Cianjur, Indonesia. Reachout Linking Communities \& Health Systems. 2014 May.

12. Alam S. Pemberdayaan Masyarakat Lokal. Makasar: Laboraturium Jurusan Sosiologi Fisip Unhas. Universitas Hasanudin, Makasar. 2009;11.

13. Effendy N. Dasar-dasar keperawatan kesehatan masyarakat. EGC;1998.

14. Mastuti TE. Studi Uji Hubungan Beberapa Faktor Kader yang Berhubungan dengan Kelangsungan Kader Posyandu di Kecamatan Panjatan Kabupaten Kulon Progo Propinsi Daerah Istimewa Yogyakarta Bulan Maret 2003 (Doctoral dissertation, Diponegoro University).

15. Silvia AR. Peran Kader Posyandu dalam Usaha Perbaikan Gizi Keluarga (UPGK)(Studi Kasus Di Desa Tambakasri Kecamatan Sumbermanjing Wetan Kabupaten Malang). SKRIPSI Jurusan Pendidikan Luar Sekolah-Fakultas Ilmu Pendidikan UM. 2011 May 24. 
Berita Kedokteran Masyarakat, Volume 33 No. 1 Tahun 2017 